\title{
凍結乾燥貝肉のヌクレオチドについて \\ On the Acid Soluble Nucleotides of the Freeze-Dried Muscle of Some Marine Invertebrates
}

\author{
(昭和 42 年 8 月 15 日 受理)
}

\author{
新井健一 小林 喜一郎 斎 藤 恒 行 \\ (Ken-ichi Arai) (Kiichiro Kobayashi) (Tsuneyuki Saito)
}

\begin{abstract}
Although detailed information on the behavior of ATP and related substances in freeze-dried foods is limited, the results of the author's experiments on the muscles of scallop, surfclam, and abalone have revealed that ATP and its related substances in these muscles are mostly fixed in the dehydrated state for 5 months, but when the products are softened with water for 1-10 minutes, the ATP is almost com. pletely decomposed, resulting in the accumulation of AMP. It has been also found that the water-holding capacity of abalone muscle is inferior to that of scallop and surfclam.
\end{abstract}

著者らはすでに水産動物筋肉中のヌクレオチドおよび その分解産物について，魚類，甲殼類，軟体類，および 貝類の代表的な種類を選び，その特異性を追求し，さ らにその眝藏条件との関係についても検討を重ねてき た ${ }^{1)}$ 。一方凍結乾燥食品については, その味, 香, ビタ ミンその他の成分の保存性などが強調され，多くの関心 が持たれているが，筋肉中のヌクレオチドの变化に関す る研究はきわめて少ない。著者らはホタテ, ウバガイ, エゾフワビなどの貝類筋肉を使用し, 凍結乾燥, 乾燥製 品の水戻しなどの操作作用によるヌクレオチドの変化を 追跡し，結果を得たのでここに報告する。

\section{実 験 方 法}

\section{1. 実験材料とその調慗}

ホタテガイ, ウバガイ, エジフワビのそれぞれ生きて いる状熊のものから試料小片 $(3.0 \times 3.0 \times 1.0 \mathrm{~cm})$ を切 除し、これを $-30^{\circ} \mathrm{C} て ゙$ 涷結し，小林の設計による凍結 乾燥機によって真空度 $0.2 \sim 0.4 \mathrm{mmHg}$, 乾燥温度 $55 \sim$ $60^{\circ} \mathrm{C}$ Kよって乾燥試料を調製した。乾燥必要時間は 4 〜 6時間であった。

2. 水戻し

乾燥食品の利用の立場に立って水㞍し実験を行なっ た。乾燥試料 $0.4 \mathrm{~g}$ をとり, $20 \mathrm{ml}$ の蒸溜水に $1 \sim 10$ 分 間浸漬し，これをガーゼによって表面に残る水分を除 き，吸水した水分量をその重量変化から算出した。

3. ヌクレオチドの定量

新鮮筋肉の場合は $1 \mathrm{~g}$, 凍結乾燥製品では $0.4 \mathrm{~g}$ をと り, 常法通り過塩素酸で抽出, 中和後, イオン交換樹脂
Amberlite IRA- $400\left(1 \mathrm{~cm}^{2} \times 13 \mathrm{~cm}\right)$ 塩酸型に吸着, 溶 剤として $\mathrm{NH}_{4} \mathrm{Cl}-\mathrm{HCl}-\mathrm{NaCl}$ 系を使用して溶出分析を行 なった。

\section{実 験 結 果}

1. 水戻しの状況

ホタテガイ, ウバガイ，エジフワビの各凍結乾燥製品 の水民しを行ない，吸水した筋肉の重量に対する吸水量 の百分率から, 水戻りの程度を比較検討した結果を第 1 表に示す。その結果によると, ホタテガイ冓燥品は外観 的にも多孔質の良質な製品となり，水民しによって吸水

Table 1. Water holding capacity of dehydrated muscle (moisture content, $\%$ of total weight)

\begin{tabular}{c|c|c|c}
\hline & scallop & surfclam & abalone \\
\hline Fresh & 79.8 & 76.7 & 70.8 \\
$\begin{array}{c}\text { Rehydration in } \mathrm{H}_{2} \mathrm{O} \\
20^{\circ} \mathrm{C} .1 \mathrm{~min} .\end{array}$ & 65.4 & 64.0 & \\
$\begin{array}{c}\text { Rehydration in } \mathrm{H}_{2} \mathrm{O} \\
20^{\circ} \mathrm{C} .5 \mathrm{~min} .\end{array}$ & 68.1 & 66.3 & \\
$\begin{array}{c}\text { Rehydration in } \mathrm{H}_{2} \mathrm{O} \\
20^{\circ} \mathrm{C} .10 \mathrm{~min} .\end{array}$ & 70.2 & 67.3 & 44.1 \\
$\begin{array}{c}\text { Rehydration in } \mathrm{H}_{2} \mathrm{O} \\
20^{\circ} \mathrm{C} .30 \mathrm{~min} .\end{array}$ & & 68.9 & 45.2 \\
$\begin{array}{c}\text { Rehydration in } \mathrm{H}_{2} \mathrm{O} \\
20^{\circ} \mathrm{C} .60 \mathrm{~min} .\end{array}$ & & & 51.9 \\
$\begin{array}{c}\text { Rehydration in } \mathrm{H}_{2} \mathrm{O} \\
0^{\circ} \mathrm{C} .5 \mathrm{~min} . \\
\text { Rehydration in } \mathrm{AcOH} \\
20^{\circ} \mathrm{C} .5 \mathrm{~min} .\end{array}$ & 68.0 & 66.2 & 49.2 \\
\hline
\end{tabular}




\section{栄 養}

しやすく，高い水庆り率を示した。ウバガイもこれに匹 敵する良い結果を得たが，エゾアワビ乾燥品は十分な水 戻りを示さず10分で44\%，1時間て $52 \%$ に止まった。一 般に漫漬時間を長くすれば水民りは進行するが，筋肉中 の可溶性成分の溶出が顕著となる。

2. 酸可溶性ヌクレオチド

ホタテガイについて得られた結果を第 2 表に示す。ホ

Table 2. Effect of freeze-drying and rehydration on acid soluble nucleotides of scallop muscle ( $\mu$ mole $/ \mathrm{g}$ muscle wet wt.)

\begin{tabular}{l|lllll}
\hline \multirow{2}{*}{ Muscle } & \multicolumn{5}{c}{ Nucleotides } \\
\cline { 2 - 6 } & HxR* & AMP & ADP & ATP & Total \\
\hline $\begin{array}{l}\text { Fresh } \\
\text { Frozen }\end{array}$ & 0 & 0.36 & 2.06 & 5.58 & 8.00 \\
\hline $\begin{array}{l}\text { Frozen, dehydrated } \\
\text { Rehydration in } \mathrm{H}_{2} \mathrm{O}\end{array}$ & 0.07 & 0.36 & 1.76 & 5.69 & 7.88 \\
$\begin{array}{c}20^{\circ} \mathrm{C} \text { 1 min. } \\
\text { Rehydration in } \mathrm{H}_{2} \mathrm{O} \\
20^{\circ} \mathrm{C} . \quad 10 \mathrm{~min} .\end{array}$ & 0.36 & 4.88 & 1.39 & 0.39 & 7.02 \\
$\begin{array}{c}\text { Rehydration in } \mathrm{H}_{2} \mathrm{O} \\
0^{\circ} \mathrm{C} . \quad 5 \mathrm{~min} .\end{array}$ & 0.18 & 5.34 & 1.13 & 0.40 & 7.05 \\
$\begin{array}{c}\text { Rehydration in } \mathrm{AcOH} \\
20^{\circ} \mathrm{C} . \quad 5 \mathrm{~min} .\end{array}$ & 0.14 & 2.12 & 3.01 & 2.06 & 7.33 \\
\hline
\end{tabular}

* Sum of $\mathrm{HxR}$ and a small amount of $\mathrm{Hx}$

タテガイ新鮮筋肉中の主成分は ATP であって，他に A DP とわずかの AMP が存在するが，これらの成分は凍 結および乾燥の過程で全く変化せずそのまま保存され る。しかし办戻しを行ならと, 非常に䫒著な変化が認め られる。すなわち, $20^{\circ} \mathrm{C}$ の蒸溜水にわずか 1 分間浸漬 しただけで約 $90 \%$ ATP は分解し, それにつれてAMP の量は増大した。この变化は $0^{\circ} \mathrm{C}$ 蒸溜水中でも起こっ た。一般に浸漬時間が長くなると分解はさらに進み，A MP に続いてイノシン (HxR) の生成が認められる。水 と比較のため，3\% の酢酸溶液を用いて浸漬実験を行な ったか，この場合には分解はかなり阻止されたが，それ でもATPの約 $60 \%$ 分解して ADP，AMPに变化してい た。

同様な実験をウハガイについて行なった結果を第 3 表 に示す。この場合すホタテガイの場合と全く類似し, 凍 結乾燥によっては生鮮品と比較して全く变化のないこと がわかるが，水戻しによってATPは急速に減少し，AM $\mathrm{P}$ が主に増加する。蒸溜水の温度が $0^{\circ} \mathrm{C}$ のときいずか に，そして 3 \%酢酸溶液の場合はかなり分解が阻止され ていた。また，浸漬にともな5可溶成分の流出はホタテ ガイより多い傾向があった。

エソ゚アワビ笳肉について得られた結果を第 4 表にあげ
Table 3. Effects of freeze-drying and rehydration on acid soluble nucleotides of surfclam muscle ( $\mu$ mole/g muscle wet wt.)

\begin{tabular}{|c|c|c|c|c|c|}
\hline \multirow{2}{*}{ Muscle } & \multicolumn{5}{|c|}{ Nucleotide } \\
\hline & $\mathrm{HxR}^{*}$ & AMP & ADP & ATP & Total \\
\hline Fresh & 0 & 0.17 & 0.75 & 3.56 & 4.48 \\
\hline Frozen & 0 & 0.18 & 0.65 & 3.46 & 4.29 \\
\hline Frozen, dehydrated & 0 & 0.21 & 0.62 & 3.66 & 4.49 \\
\hline $\begin{array}{c}\text { Rehydration in } \mathrm{H}_{2} \mathrm{O} \\
20^{\circ} \mathrm{C} .1 \mathrm{~min} .\end{array}$ & 0 & 2.68 & 0.96 & 0.45 & 4.09 \\
\hline $\begin{array}{c}\text { Rehydration in } \mathrm{H}_{2} \mathrm{O} \\
20^{\circ} \mathrm{C} . \quad 5 \mathrm{~min} .\end{array}$ & 0.20 & 2.50 & 0.64 & 0.19 & 3.53 \\
\hline $\begin{array}{c}\text { Rehydration in } \mathrm{H}_{2} \mathrm{O} \\
0^{\circ} \mathrm{C} . \\
\text { min. }\end{array}$ & 0 & 2.05 & 1.18 & 0.70 & 3.93 \\
\hline $\begin{array}{c}\text { Rehydration in } \mathrm{AcOH} \\
20^{\circ} \mathrm{C} .5 \mathrm{~min} .\end{array}$ & 0 & 0.44 & 1.29 & 2.35 & 4.08 \\
\hline
\end{tabular}

Table 4. Effects of freeze-drying and rehydration on acid soluble nucleotides of abalone muscle ( $\mu$ mole/g muscle wet wt.)

\begin{tabular}{c|ccccc}
\hline \multirow{2}{*}{ Muscle } & \multicolumn{5}{|c}{ Nucleotide } \\
\cline { 2 - 6 } & Ad & AMP & ADP & ATP & Total \\
\hline $\begin{array}{c}\text { Fresh } \\
\text { Frozen }\end{array}$ & 0 & 0.12 & 0.30 & 4.28 & 4.70 \\
\hline $\begin{array}{l}\text { Frozen, dehydrated } \\
\text { Rehydration in } \mathrm{H}_{2} \mathrm{O}\end{array}$ & 0 & 0.13 & 0.33 & 4.20 & 4.66 \\
$\begin{array}{c}20^{\circ} \mathrm{C} \text { 10min. } \\
\text { Rehydration in } \mathrm{H}_{2} \mathrm{O}\end{array}$ & 0 & 0.95 & 0.88 & 1.71 & 3.54 \\
$\begin{array}{c}20^{\circ} \mathrm{C} . \text { 30min. } \\
\text { Rehydration in } \mathrm{H}_{2} \mathrm{O} \\
0^{\circ} \mathrm{C} \text { 20min. }\end{array}$ & 0 & 1.05 & 0.89 & 1.42 & 3.36 \\
$\begin{array}{c}\text { Rehydration in } \mathrm{AcOH} \\
20^{\circ} \mathrm{C} \text { 20min. }\end{array}$ & 0 & 0.32 & 0.85 & 2.31 & 3.48 \\
\hline
\end{tabular}

る。この場合すホタテガイ, ウバガイの場合とよく類似 していた。すなわち, 新鮮筋肉中の ATP, ADP, AMP 量は凍結および乾燥の過程で全く変化を受けないが，製 品を水庆しするときは, かなり速い ATP の分解が起こ る。浸漬時間が長くなると分解は一㬝進むが，ホタテカ イ,ウバガイの場合ほど完全な消失はみられなかった。 $20^{\circ} \mathrm{C}$ で30分間漫漬しても，ATPはな扰 $34 \%$ 残存してい た。 $0^{\circ} \mathrm{C}$ の蒸溜水および $3 \%$ 酢酸溶液に浸清するときは ATPの分解はかなり阻止された。また, 浸漬液中への可 溶性成分の流出すホタテガイの場合と同程度であった。

次にホタテガイの凍結乾燥品を貯蔵し, 筋肉中の酸可 溶ヌクレオチドの変化を追跡した結果を第 5 表に示す。 この結果によると, ホタテガイ筋肉乾燥品中の ATPを 主成分とするヌクレオチドは, デシケーター中で 5 カ月 間詝藏してす全く変化せず，乾燥状態では辢品はかなり 
Table 5. Changes in acid soluble nucleotides in scallop muscle during storage ( $\mu$ mole/ g muscle wet wt.)

\begin{tabular}{c|llllll}
\hline \multirow{2}{*}{ Muscle } & \multicolumn{5}{|c}{ Nucleotide } \\
\cline { 2 - 7 } & HxR & AMP ADP & ATP & Total \\
\hline $\begin{array}{c}\text { Frozen, dehydrated } \\
\begin{array}{c}\text { Stored in dessicator } \\
\text { for 5 months }\end{array}\end{array}$ & 0 & 0.35 & 1.17 & 4.55 & 6.07 \\
$\begin{array}{c}\text { Stored at room temp. } \\
\text { for 30 days }\end{array}$ & 0 & 1.74 & 2.62 & 1.68 & 6.04 \\
$\begin{array}{c}\text { Rehydration in } \mathrm{H}_{2} \mathrm{O} \\
27^{\circ} \mathrm{C} . \quad 5 \text { min. }\end{array}$ & 0.47 & 3.11 & 1.19 & 0.47 & 5.24 \\
$\begin{array}{c}\text { Stored at } 6^{\circ} \mathrm{C} \text {. for 24 } 24 \\
\text { hours after } \\
\text { rehydration }\end{array}$ & 5.02 & 0.27 & 0.34 & 0.09 & 5.72 \\
\hline
\end{tabular}

安定していることを示す。しかし， $30^{\circ} \mathrm{C}$ のふ卯器中で は，30日間の貯藏によって ATP の分解は徐々に進んで いた。乾燥品について水戻しを行ならと, 既述の通り, $\mathrm{ATP} \rightarrow \mathrm{AMP}$ の変化が主に起こるが，水民し後さらに 6 ${ }^{\circ} \mathrm{C} て 24$ 時間貯藏すると, $\mathrm{AMP} \rightarrow \mathrm{HxR}$ の変化がさらに 進んでいた。そして全体の約 $90 \%$ H $\mathrm{HR}$ となってい た。

\section{考察}

ホタテガイ, ウバガイ, エジフワビなど貝類筋肉中の ATP は凍結乾燥の過程では全く分解せず，慗品の水民し によって急速に分解することがわかったが，分解は単に 脱燐酸されるたけけてなく，筋肉の保藏実験によって見出 された分解生成物と同種の化合物が見出されている ${ }^{2)}$ 。 したがって筋肉を凍結する過程では，筋肉中に存在して いた ATP 並びに関連物質の分解汇関与するいくつかの 醅素活性は保存され，これらの䤃素系は水戻しによって 急速に復元するるのと考えられる。この事実はホタテガ イ凍結乾燥筋肉の貯藏実験に扎いても認められる。すな わち乾燥品中の ATP を主成分とする関連化合物は, デ シヶーター中で 5 カ月間貯藏しても全く变化しない。し
たがって乾燥状態では製品はかなり安定していることが わかるが, $30^{\circ} \mathrm{C}$ のふ贸器中で30日間詝藏すれば, ATP の分解は徐々に進み，水㞍しを行ならと既述の通り， $\mathrm{A}$ $\mathrm{T} \mathrm{P} \rightarrow \mathrm{AMP}$ の変化が主として起こるが, 詝藏時間の経 過とともにAMP $\rightarrow \mathrm{HxR}$ 変化が進む。これらのことか ら考元て筋肉中の ATP-ase, myokinase, phosphatase' deaminase などの諸酵索作用は凍結乾燥倸よって大きな 影䱥を受けることなしに保存され，水分が与えられてそ の活性が改めて確認されたことになる。なお，ATP を中 心とする関連化合物の变化は, 新井 ${ }^{3}$ が新鮮筋の自己消 化過程に拄いて明らかにした諸点と全く一致している。

$$
\text { 要 約 }
$$

ホタテ, ウバガイ, エジフワビなどの貝類筋肉を涷結 乾燥し,さらにこれを水戻しして, これらの操作中に起 こるAＴＰおよび関連化合物の变化を追求した。その結 果, 凍結乾燥の段階では何れの筋肉の場合もこれらの成 分含量は新鮮筋のそれと全く一致して殆んぞ変化の無い ことを認めた。また, 水㞍しに際しては, ホタテ, ウハ ガイではかなりよく復元されたが, アワビでは復元性は きわめて悪かった。さらに酸溶性ヌクレオチドについて は，A T Pはきわめて短時間のうちに変化して主として AMPの蓄積するのが認められ，さらに浸漬時間を長く 寸ると, AMPから HxRの生成するのが認められた。ま た, 凍結乾燥品をデシケーター中で 5 カ月にわたり保存 した場合です変化はなかったが，これを水庆しすると同 時に $\mathrm{AT} \mathrm{P}$ の急速な変化が認められた。したがって乾燥 食品を水分をさけて保存した場合は筋肉中に含まれる醉 索もかなり長期にわたって活性を復元できる状態にある ことを知った。

\section{文献}

1) 斎藤恒行: 日本水産学会誌, 27,461 (1961)

2) Arai, K. \& Saito, T. : Nature, 192, 451 (1961)

3）新井健一：日本水産学会誌, 32,174 (1966)

(北海道大学水産学部) 